\title{
Leader
}

\section{Microorganisms in the aetiology of atherosclerosis}

\author{
S A Morré, W Stooker, W K Lagrand, A J C van den Brule, H W M Niessen
}

\begin{abstract}
Recent publications have suggested that infective pathogens might play an important role in the pathogenesis of atherosclerosis. This review focuses on these microorganisms in the process of atherosclerosis. The results of in vitro studies, animal studies, tissue studies, and serological studies will be summarised, followed by an overall conclusion concerning the strength of the association of the microorganism with the pathogenesis of atherosclerosis. The role of the bacteria Chlamydia pneumoniae and Helicobacter pylori, and the viruses human immunodeficiency virus, coxsackie $B$ virus, cytomegalovirus, Epstein-Barr virus, herpes simplex virus, and measles virus will be discussed.

(F Clin Pathol 2000;53:647-654)
\end{abstract}

Keywords: atherosclerosis; Chlamydia pneumoniae; Helicobacter pylori

The pathogenesis of atherosclerosis is a subject of much debate, but it is now generally thought to be a chronic inflammatory disease. ${ }^{1}$ The initiation and progression of atherosclerosis seems to be related to the location and extent of the inflammatory reactions. ${ }^{2-4}$ Recent publications suggest that infective pathogens also play an important role in the process of atherosclerosis. Thus, local infection could either react directly with the vessel wall or indirectly through initiation of immunological responses. ${ }^{5}$

In this review we will discuss the role of microorganisms (bacteria and viruses) in the process of atherosclerosis.

\section{Bacteria}

Chronic dental bacterial infections are strongly associated with atherosclerosis. ${ }^{6-8}$ Although the chronological sequence of infection and the initiation of atherosclerosis is still not clear, it can be argued that atherosclerosis is the cause and not the consequence of dental infections because individuals with coronary atherosclerosis might also have compromised arterial circulation in the peridontium. However, a recent study by Adams et al strongly argues against this explanation. ${ }^{9}$

Nevertheless, Meier et al have shown retrospectively that previous use of tetracyclines and quinolones was associated with a lower risk of acute myocardial infarction, providing indirect evidence that infection with microorganisms susceptible to tetracycline antibiotics might be involved in the aetiology of ischaemic heart disease. $^{10}$

We will focus on the role of bacteria with the supposed strongest association with atherosclerosis, namely Chlamydia pneumoniae and Helicobacter pylori.

\section{CHLAMYDIA PNEUMONIAE}

In vitro studies

In vitro experiments have shown that $C$ pneumoniae induces human macrophage or foam cell formation, a key event in early atheroma development, via chlamydial lipopolysaccharide, suggesting a role for $C$ pneumoniae in atherogenesis. ${ }^{11}{ }^{12}$ Furthermore, it has been found that endothelial cells, smooth muscle cells, and macrophages are capable of supporting the growth of $C$ pneumoniae..$^{13}$ In addition, an association between $C$ pneumoniae infection and a specific immune response has been suggested. ${ }^{14}$ Studies in men with coronary heart disease suggest that $C$ pneumoniae possibly contributes to the process of coronary atherosclerosis by chlamydia specific, cell mediated responses, predominantly induced by antigenic structures that are similar among different species of chlamydia. ${ }^{14}$ Indeed, a coronary strain, $C$ pneumoniae A-03, has been isolated and shown to stimulate production of monocyte chemotactic protein 1 , interleukin 8 (IL-8), and soluble intercellular adhesion molecule 1 in vitro. ${ }^{15}$ In surgical specimens of human carotid atherosclerotic plaques, induction of macrophage functions by $C$ pneumoniae was also found. ${ }^{16}$ Interestingly, percutaneous transluminal coronary angioplasty also induces stimulation of the humoral immune response against $C$ pneumoniae and supports the idea that plaque disruption during angioplasty might expose hidden $C$ pneumoniae antigens to the immune system. ${ }^{17}$

These humoral immune reactions might be related to bacterial heat shock proteins (HSPs), such as chlamydia HSP60, which may play an important role in the process of vascular endothelial injury, a key event in the pathogenesis of atherosclerosis. ${ }^{18}$

\section{Animal studies}

In vivo experiments in rabbits showed that intranasal $C$ pneumoniae infection accelerates intimal thickening (which could be inhibited by 
azithromycin) and inflammatory atherosclerosis like changes in the aorta. ${ }^{19} 20$ In addition, intranasal inoculations of $C$ pneumoniae in ApoE deficient transgenic mice and C57BL/6J mice (these mice develop atherosclerosis on an atherogenic diet) resulted in $C$ pneumoniae localisation in atheroma, suggesting a tropism of $C$ pneumoniae to the lesion. ${ }^{21}$ In a murine model system, both $C$ pneumoniae strains, AR39 and MoPn, were detected in the aorta of mice infected with the corresponding strain. However, only mice infected with AR39 had enhanced atherosclerotic lesions, suggesting that this $C$ pneumoniae strain might possess a unique atherosclerotic property. ${ }^{22}$ Thus, these animal studies strengthen the aetiological link between $C$ pneumoniae and atherosclerosis.

\section{Serological studies}

Serological studies and the detection of $C$ pneumoniae in atheromatous lesions were the first indications of an association between $C$ pneumoniae and atherosclerosis. ${ }^{23}$ Seropositivity for $C$ pneumoniae was associated with an increased risk for future cardiovascular disease, namely stroke, ${ }^{24}$ carotid wall thickening, ${ }^{25}$ and coronary heart disease. ${ }^{26}$. Chronic $C$ pneumoniae infection seemed to be associated with a serum lipid profile considered to increase the risk of atherosclerosis, supporting the hypothesis that infections do play an (indirect) role in the pathogenesis of atherosclerosis. ${ }^{27}$ In addition, $C$ pneumoniae DNA can be detected in circulating white blood cells by the polymerase chain reaction (PCR). ${ }^{28} 29$ Using this technique, an association between coronary heart disease and circulating $C$ pneumoniae DNA in men, but not in women, was found. ${ }^{30}$

However, in a large scale study, Ridker et al found no evidence of an association between $C$ pneumoniae IgG seropositivity and risk for future myocardial infarction. ${ }^{31}$ Furthermore, Altman et al found that the presence of IgG antibodies to $C$ pneumoniae in the serum is not predictive of acute arterial complications. ${ }^{32}$ Therefore, seroepidemiological studies are contradictionary with respect to the role of $C$ pneumoniae in atherosclerosis.

Tissue studies

By means of immunohistochemistry, PCR, and nested PCR, $C$ pneumoniae was detected in carotid endarterectomy specimens, within atherosclerotic plaques, and in endothelial cells, macrophages, and smooth muscle cells, suggesting a direct role of $C$ pneumoniae in carotid artery atherosclerosis. ${ }^{33-36}$ Using PCR and immunohistochemistry, $C$ pneumoniae was detected in arterial biopsies from femoral, popliteal, and coronary arteries, as well as in the aorta, indicating that the organism is widespread in atherosclerosis of the vascular system. $^{37-42}$. Bartels et al even found that occluded aorta-coronary venous grafts harbour $C$ pneumoniae (but not cytomegalovirus). ${ }^{43}$

Others have demonstrated viable $C$ pneumoniae by means of cell culture in coronary atheromas, carotid endarterectomy specimens, and abdominal aneurysm. ${ }^{15} 344^{46}$ Chlamydia pneumoniae has also been demonstrated in many tissues by electron microscopy, supporting the true evidence of $C$ pneumoniae particles. ${ }^{345-48}$

In contrast, in another study of carotid endarterectomy specimens, bacterial and viral cultures in plaques were negative. ${ }^{49}$ An Autralian study using PCR in postmortem material did not detect $C$ pneumoniae in coronary arteries or carotid endarterectomy specimens. ${ }^{50}$ In addition, Lindholt et al could not detect $C$ pneumoniae in symptomatic aneurysms of the abdominal aorta. Therefore, they suggested that these aneurysms and atherosclerosis might be two different disease entities. ${ }^{51}$

Finally, Andreasen et al could not detect $C$ pneumoniae in calcific or degenerative atherosclerotic aortic heart valve disease. ${ }^{52}$ However, Nystromrosander et al did detect $C$ pneumoniae in aortic valves using electron microscopy. ${ }^{48}$

\section{Treatment}

Pilot studies have shown that antibiotic treatment (azithromycin and roxithromycin) improves the clinical outcome in patients with myocardial infarction and acute non- $Q$ wave coronary syndromes. ${ }^{5354}$ Recently, the final ROXIS study showed that roxithromycin appeared to extend the clinical benefit of preventing death and re-infarction for at least six months after initial treatment. ${ }^{55}$

In contrast, Anderson et al have shown that in patients with coronary heart disease, positive for $C$ pneumoniae antibodies, global tests for $\mathrm{C}$ reactive protein (CRP), IL-1, IL-6, and tumour necrosis factor $\alpha$ (TNF- $\alpha$ ) improved at six months with azithromycin. However, no differences in antibody titres and clinical events were seen. ${ }^{56}$ Thus, controlled trials are needed to establish the therapeutic role of antibiotics in peripheral arterial disease. ${ }^{57}$

\section{Conclusion}

The Koch-Henle criteria for proof of the aetiology of $C$ pneumoniae infection in atherosclerosis seem to be largely fulfilled: correlation of atherosclerosis with antibodies against $C$ pneumoniae; detection of $C$ pneumoniae in atheromas with different techniques; international studies with macrolides in coronary heart disease were successful; target cells of atherosclerosis can be infected with $C$ pneumoniae in vitro; and animal experiments have been positive. ${ }^{58}$ However, several studies reported that no $C$ pneumoniae could be detected in atherosclerotic lesions. It is not known whether this is related to technical problems, the specimens that were studied, or geographical differences. Furthermore, it is unclear whether $C$ pneumoniae initiates the process of atherosclerosis, facilitates progression of existing plaques, or merely colonises the lesions. ${ }^{59}$

\section{HELICOBACTER PYLORI}

In vitro study

In an in vitro study it has been shown that polyunsaturated fatty acids inhibit the growth of $H$ pylori and prevent/arrest atherosclerosis. ${ }^{60}$ 
Serum studies

Laurila et al found that serum triglyceride and total cholesterol concentrations were significantly higher in men with IgG and IgA against $H$ pylori than in men with no signs of infection, supporting the hypothesis that chronic infection with $H$ pylori might modify the serum lipid profile in a way that increases the risk of atherosclerosis. ${ }^{61}$

In duplex ultrasound studies that established carotid atheroma load in combination with serum $H$ pylori measurements, it was concluded that chronic $H$ pylori infection is an independent risk factor for ischaemic cerebrovascular disease and may act, at least in part, by increasing atherosclerosis. ${ }^{62}$ Another study suggested that it is possible that exposure to $H p y$ lori and other microorganisms leads to an increased risk of clinically manifest coronary artery disease by an autoimmune process (anti-HSP 60/65 antibodies), in patients submitted for routine angiography. ${ }^{63} 64$

In contrast, in other prospective case cohort designs among middle aged men and women, $H$ pylori seropositivity was not associated with coronary heart disease, or with increased mean intima-media thickness of the carotid artery, suggesting that $H$ pylori is probably not an important contributor to clinical coronary heart disease events. ${ }^{656}$

Tissue study

In patients with aortic aneurysms, seropositivity for $\mathrm{H}$ pylori was found. However, PCR for $H$ pylori was negative, making the possibility of a direct involvement of $H$ pylori in atherosclerotic aortic aneurysms less tenable. ${ }^{38}$

\section{Conclusion}

To date, there is no convincing evidence supporting the presence of $H$ pylori within atherosclerotic plaques, and seroepidemiological evidence is contradictionary.

\section{Viruses}

Pesonen et al investigated 175 children (0-15 years of age) who had undergone necropsy and found that infections in general and viral infections in particular seem to be associated with intimal thickening, which might predispose coronary arteries to atherosclerosis ${ }^{67}$ We will focus on the role of human immunodeficiency virus, coxsackie B virus, cytomegalovirus, Epstein-Barr virus, herpes simplex virus, and measles virus in atherosclerosis.

\section{HUMAN IMMUNODEFICIENCY VIRUS (HIV) \\ Serological studies}

Constans et al have shown that, although no clinically relevant atherosclerotic lesions were found, plaques occurred more often in patients with HIV than in controls. ${ }^{68}$ During postmortem examination of eight HIV seropositive male patients, Paton et al found major atherosclerosis in coronary arteries in the absence of an associated cardiovascular risk factor.

They concluded that viral infection, either HIV or coexisting herpesviruses, played a role in the development of the coronary lesions. ${ }^{69}$

\section{Conclusion}

It is difficult to establish whether HIV itself, or an opportunistic pathogen, or both, are causally related to the process of atherosclerosis.

COXSACKIE B VIRUS (CBV)

Animal study

Recent murine model work support the idea that $\mathrm{CBV}$, a member of the enterovirus genus, and immune cells cooperate and play a role in arterial lipid accumulation, possibly acting as initiating factors for atherosclerosis. ${ }^{70}$

\section{Serological studies}

One of the most recent studies on CBV showed that high concentrations of enterovirus specific antibodies were associated with a risk of myocardial infarction in men. ${ }^{71}$ However, an association between antibodies to CBV and myocardial infarction has not been found in all studies. $^{72} 73$

\section{Conclusion}

Further studies are needed to evaluate whether, and by which mechanism, enterovirus infections are involved in the pathogenesis of atherosclerosis and the development of myocardial infarction.

\section{CYTOMEGALO VIRUS (CMV)}

In vitro studies

In vitro studies have shown that CMV infection can potentially lead to infection of blood vessel endothelium, thereby inducing damage to endothelium, and infection of smooth muscle cells, suggesting a role in atherosclerosis. ${ }^{74-78}$ Indeed, in cultures of smooth muscle cells of carotid artery plaques, CMV (but not herpes simplex virus 1 or 2) was detected by means of immunohistochemistry in $25 \%$ of cells. ${ }^{79}$ However, no replicating CMV was found by electron microscopy, suggesting that the artery walls might be a site of CMV latency ${ }^{79}$.

\section{Animal studies}

Inoculation of $\mathrm{BALB} / \mathrm{c}$ mice with $\mathrm{CMV}$ resulted in the development of atherosclerosis; that is, immune injury and high low density lipoprotein cholesterol. ${ }^{80}$ In rats, it was found that an active CMV infection of arterial smooth muscle cells can be established in vivo. Interestingly, neointimal smooth muscle cells were far more susceptible to CMV infection than medial smooth muscle cells. ${ }^{81}$

\section{Serological studies}

In a case control study and the ARIC (atherosclerosis risk in communities) study, an association was found between the serum CMV antibody titre and carotid intimal-medial thickness, which is in line with a causal role for CMV in atherosclerosis. ${ }^{82}{ }^{83} \mathrm{CMV}$ infection has also been identified as an independent risk factor in re-stenosis after coronary angioplasty. ${ }^{84} 85$ In men undergoing vascular surgery for atherosclerosis, the prevalence of CMV antibodies was higher in the surgical group than in the control group (not significant for herpes simplex virus 1 or 2 ), suggesting that periodically activated virus might have a role in the 
pathogenesis of atherosclerosis. ${ }^{86}$ In addition, serum CMV antibody titres were higher in patients with atherosclerosis and diabetes than in patients without diabetes, suggesting that CMV might play a role in the development of clinical atherosclerosis in patients with diabetes mellitus. ${ }^{87}$

In contrast, in serological studies of immune responses to $\mathrm{CMV}$, combined with the correlation of angiographically assessed atherosclerosis, it was concluded that multiple reactivation of latent viruses might be a consequence rather than a cause of atherosclerosis. ${ }^{88}$ Furthermore, another study showed that prior infection with CMV is not a major risk factor for angiographically demonstrated primary coronary artery atherosclerosis. ${ }^{89}$ In addition, Tiran et al found that anti-CMV positivity is not a major risk factor at the time of disease manifestation, implying that CMV does not play an important role in the pathogenesis of atherosclerosis. ${ }^{90}$

Tissue studies

Using PCR, $90 \%$ of the samples obtained from patients with grade III atherosclerosis were shown to contain CMV viral nucleic acids, compared with $53 \%$ of patients with grade I atherosclerosis, indicating a role for this virus in the pathogenesis of atherosclerosis. ${ }^{91}$ However, CMV was also found (by means of in situ hybridisation and immunohistochemistry) in abdominal aortas, femoral, and coronary arteries in atherosclerotic as well as control material, suggesting that the human arterial wall might be a site of latency of this virus. ${ }^{92}$ Other findings suggest that the persistent expression of CMV immediate early genes in the vessel wall might play a role in the vascular cellular responses, including progression of atherosclerosis or vasculitis in vivo. ${ }^{93}$

\section{Transplantation}

Heart transplant recipients who are immunosuppressed and who are also actively infected with CMV are prone to develop accelerated atherosclerosis in the transplanted organ, ${ }^{94}$ with more frequent rejection. ${ }^{95}$ In serological tests after cardiac transplantation CMV infection was found in $77 \%$ of patients, suggesting a relation between $\mathrm{CMV}$ infection and rapidly progressive coronary atherosclerosis after cardiac transplantation. ${ }^{96}$ Another study of patients with cardiac transplants found serological evidence of past $C$ pneumoniae and CMV infection. However, $C$ pneumoniae does not appear to have an independent role or synergistic relation to CMV in the development of transplant associated atherosclerosis. ${ }^{97}$

\section{Conclusion}

In vitro and immunohistochemical studies have provided mainly circumstantial evidence for the involvement of CMV in human atherosclerosis, whereas seroepidemiologic studies suggest that a periodically activated latent infection of CMV is present in patients with atherosclerosis. ${ }^{98}$ In general, the conclusions of seroepidemiological studies are contradictionary.
EPSTEIN-BARR VIRUS (EBV)

Serological studies

A study of antibodies against EBV in sera, combined with angiography, suggested that reactivation of latent $\mathrm{EBV}$ is a consequence rather than a causal factor of atherosclerosis. ${ }^{99}$

Tissue study

Using immunohistochemistry and PCR, EBV could not be found in early and advanced atheromatous changes in coronary arteries, or in lesion free areas in the thoracic aorta of young trauma victims. ${ }^{100}$

\section{Transplantation}

An association between atherosclerosis and a previous EBV infection was demonstrated in heart transplants. ${ }^{101}$

Conclusion

Although seroepidemiological studies implicate a role of EBV in atherosclerosis, to date, EBV has not been found in atherosclerotic lesions.

HERPES SIMPLEX VIRUS (HSV)

In vitro studies

An in vitro study in HUVEC cells (cultured primary endothelial cells from the human umbilical vein) indicated that latent infection of vascular cells with HSV might play a pathogenic role in the development of human atherosclerosis. ${ }^{102}$ Another study suggested that the efficiency of HSV-1 infection of smooth muscle cells derived from adult rats is greater than of those from pup rats. This could be important because age is a risk factor for the development of atherosclerosis. ${ }^{103}$ It has also been shown that HSV infection leads to lipid accumulation in vascular cells. Furthermore, HSV infection of endothelial cells attracts leucocytes, with subsequent inflammatory damage. HSV also induces procoagulant changes on endothelium, with increased thrombin generation and platelet adhesion. These changes are more or less characteristic for atherosclerosis. ${ }^{104-108}$

\section{Animal study}

It has been shown that HSV causes atherosclerosis in experimental animals. ${ }^{94} 109$ These authors suggest that lipid depositions in atherosclerosis may result in part from virus induced changes in the cholesterol metabolism of host cells, as was found in cultured smooth muscle cells.

\section{Tissue studies}

Histological studies and in situ DNA hybridisation in young trauma victims have shown HSV associated with areas showing early and advanced atheromatous changes in coronary arteries and with lesion free as well as lesional areas in the thoracic aorta. This supports the concept that HSV might play a direct or indirect role in the pathogenesis of human atherosclerosis. ${ }^{100}$ In coronary biopsies obtained during coronary artery bypass graft surgery, immunohistochemistry and situ hybridisation demonstrated HSV-2 in $45 \%$ of biopsies and also one case of HSV-1. ${ }^{110}$ 
Table 1 Studies supporting the aetiological link between microorganisms and atherosclerosis

\begin{tabular}{|c|c|c|c|c|c|}
\hline \multirow[b]{2}{*}{ Microorganism } & \multicolumn{5}{|l|}{ Key references } \\
\hline & In vitro studies & Animal studies & Serological studies & Tissue studies & Treatment \\
\hline \multicolumn{6}{|l|}{ Bacteria } \\
\hline Chlamydia pneumoniae & $11,12,13,15,18$ & $19,20,21$ & $24,25,26,27,30$ & $33,36,37,39,41,43$ & $48,49,50$ \\
\hline Helicobacter pylori & 55 & - & $56,58,59$ & - & - \\
\hline \multicolumn{6}{|l|}{ Viruses } \\
\hline Human immunodeficiency virus (HIV) & - & - & 63,64 & - & - \\
\hline Coxsackie $B$ virus (CBV) & - & 65 & 66 & - & - \\
\hline Cytomegalovirus (CMV) & $70,72,73,74$ & 75,76 & $78,80,81,82$ & 86,87 & - \\
\hline Epstein-Barr virus (EBV) & - & - & 94,96 & - & - \\
\hline Herpes simplex virus 1 and 2 (HSV) & $97,98,99,101,103$ & 89,104 & - & 95,105 & - \\
\hline Measles virus & 108 & - & - & - & - \\
\hline
\end{tabular}

Table 2 Studies contradicting the aetiological link between microorganisms and atherosclerosis

\begin{tabular}{|c|c|c|c|c|c|}
\hline \multirow[b]{2}{*}{ Microorganism } & \multicolumn{5}{|c|}{ Key references } \\
\hline & $\begin{array}{l}\text { In vitro } \\
\text { studies }\end{array}$ & $\begin{array}{l}\text { Animal } \\
\text { studies }\end{array}$ & $\begin{array}{l}\text { Serological } \\
\text { studies }\end{array}$ & Tissue studies & Treatment \\
\hline \multicolumn{6}{|l|}{ Bacteria } \\
\hline Chlamydia pneumoniae & - & - & 31,32 & $44,45,46,47$ & 51 \\
\hline Helicobacter pylori & - & - & 60,61 & 38 & - \\
\hline \multicolumn{6}{|l|}{ Viruses } \\
\hline Human immunodeficiency virus (HIV) & - & - & - & - & - \\
\hline Coxsackie B virus (CBV) & - & - & 67,68 & - & - \\
\hline Cytomegalovirus (CMV) & - & - & 84,85 & - & - \\
\hline Epstein-Barr virus (EBV) & - & - & - & 95 & - \\
\hline Herpes simplex virus 1 and 2 (HSV) & - & - & - & - & - \\
\hline Measles virus & - & - & - & - & - \\
\hline
\end{tabular}

\section{Conclusion}

In humans, clinical, epidemiological, and molecular biology studies implicate a relation between herpesviruses and atherosclerosis. ${ }^{94111}$ However, it also has been hypothesised that mechanical abrasion might reactivate latent HSV (and CMV) infection in endothelial cells, particularly those exposed to high shearing forces-for example, at vessel bifurcations. This mechanism might be responsible for the endothelial damage, clotting, and atheroma formation often found at these sites. ${ }^{112}$

MEASLES VIRUS

In vitro study

An in vitro study in isolated endothelium/ smooth muscle cells indicated that measles virus infection might be a risk factor for atherosclerosis, by means of damaging endothelial cells and initiating proliferation of smooth muscle cells. ${ }^{113}$

\section{Conclusion}

The role of measles virus has not been studied extensively and, to date, no in vivo data are available.

\section{Discussion}

Microorganisms as aetiological agents might provide new insights into some unexplained aspects of atherosclerosis. A higher incidence of coronary heart disease in young men coincides with the remarkable androtropism of bacterial diseases, whereas the low incidence of coronary artery disease in France could be explained by a much higher use of antichlamydial antibiotics. However, the low incidence of atherosclerosis in the tropics, despite a high frequency of chlamydial infection, is difficult to explain. ${ }^{58}$

It has also been suggested that low grade infections might be one of the causes of the inflammatory reaction observed in atheroscle- rotic lesions and acute ischaemic syndromes, reflected in raised concentrations of CRP, ${ }^{109} 114$ suggesting that the rise in CRP is not a risk factor, but a sign of an active chronic infection. However, immunohistochemical studies of atherosclerotic lesions suggested that CRP might promote atherosclerosis locally by activating the complement system and inducing foam cell formation. ${ }^{115}$ This contradicts the idea that the rise in CRP merely reflects baseline inflammation.

Indeed, seroepidemiological data suggest an association between pathogens and clinical events related to atherosclerosis (table 1). However, they cannot distinguish between a causal relation and secondary infection. Furthermore, both serological and epidemiological data are contradictionary in different studies (table 2).

Some tissue studies have found antigens, genetic material, or cultivatable infectious agents in association with the inflammatory lesions. However, it is unclear whether these agents initiate arterial lesions or exacerbate those lesions already present. It is also unknown whether infectious agents in atherosclerotic lesions are directly pathogenic or act through immune responses to microbial antigens, which crossreact with normal human antigens. Recently, an interesting study has shown that a peptide from the murine heart muscle specific $\alpha$ myosin heavy chain has sequence homology to the $60 \mathrm{kDa}$, cysteine rich, outer membrane of $C$ pneumoniae, $C$ psittaci, and $C$ trachomatis, leading to the production of autoantibodies to heart muscle specific epitopes in mice. ${ }^{116}$ This suggests that chlamydia mediated heart disease is induced by antigenic mimicry of a heart muscle specific protein.

Overall, $C$ pneumoniae is the agent with the most evidence for a causal association with 
atherosclerosis (provided by seroepidemiological, pathological, and animal models, and in vitro studies). Although Koch's postulates seem to be fullfilled for $C$ pneumoniae infection and atherosclerosis, definitive proof that a particular microorganism causes atherosclerosis may not come from this direction, but from the prevention of primary infection by vaccination or the eradication of the agent by antimicrobials. However, if successful, there is a danger that an increase in prescription of these antibiotics could result in an increase in resistence to antibiotics.

In animals, polyclonal immunoglobulin preparations inhibited atherosclerosis via modulation of $\mathrm{T}$ cell activity and/or antibody production. Therefore, immunomodulation might be another effective way to prevent and/or treat atherosclerosis. ${ }^{117}$ In addition, studies of the prophylactic use of antiviral agents, such as ganciclovir or CMV vaccine, especially in patients at high risk of developing atherosclerosis (such as heart transplant patients), will allow an alternative prevention strategy for coronary heart disease.

If antibiotic, antiviral, and/or immunomodulatory agents do appear to attenuate the atherosclerotic process, the public health implications will be enormous.

In conclusion, arguments for and against the role of infection in atherosclerosis have appeared with equal regularity. However, for some of these infectious agents (CMV, but especially $C$ pneumoniae), evidence for their role in atherosclerosis seems relatively strong. Nevertheless, the mechanism by which they induce their pathological effect is still unclear. A direct effect would have important implications for this widespread disease because adequate antibiotic treatment is possible. If the effect is indirect - for example, by the process of molecular mimicry, as has been postulated recently, innovative ways of exploring the pathogenesis of human disease in general will be needed.

This work was supported by the Netherlands Heart Foundation, grant no 93-119. Dr Niessen is a recipient of the Dr B Dekker programme of the Netherlands Heart Foundation.

1 Capron L, Wyplosz B. The infection theory in atherosclerosis. Arch Mal Coeur Vaiss 1998;91:21-6.

2 Libby P, Aikawa M. New insights into plaque stabilisation by lipid lowering. Drugs 1998;56:9-13.

3 Jander S, Sitzer M, Schumann R, et al. Inflammation in high-grade carotid stenosis: a possible role for macrophages and T cells in plaque destabilization. Stroke 1998;29:162530 .

4 Mendall MA, Patel P, Ballam L, et al. C reactive protein and Mendall MA, Patel P, Ballam L, et al. C reactive protein and its relation to cardiovascular risk factors: a popula
based cross sectional study. $B M \mathcal{F} 1996 ; 312: 1061-5$.

5 Muhlestein JB. Bacterial infections and atherosclerosis. $f$ Investig Med 1998;46:396-402.

6 Beck JD, Slade GD. Epidemiology of peridontal diseases. Current Opinion Peridontology 1996;3:3-9.

7 Matilla KJ, Valle MS, Nieminen MS, et al. Dental infections and coronary atherosclerosis. Atherosclerosis 1993;103:20511.

8 Matilla KJ. Dental infections as a risk factor for acute myocardial infarction. Eur Heart f 1993;14:51-3.

9 Adams MR, Nakagomi A, Keech A, et al. Carotid intima-media thickness is only weakly correlated with the thich 1995;92:2127-34.

10 Meier CR, Derby LE, Jick SS, et al. Antibiotics and risk of subsequent first-time acute myocardial infarction. $7 A M A$ 1999;281:427-31.

11 Kalayoglu MV, Byrne GI. A Chlamydia pneumoniae component that induces macrophage foam cell formation
is chlamydial lipopolysaccharide. Infect Immun 1998;66: is chlamydiat
$5067-72$.
12 Kalayoglu MV, Byrne GI. Induction of macrophage foam ell formation by Chlamydia pneumoniae. $\mathcal{F}$ Infect Dis 998:177:725-9.

13 Godzik KL, O'Brien ER, Wang SK, et al. In vitro susceptibility of human vascular wall cells to infection with Chlamydia pneumoniae. F Clin Microbiol 1995;33:241114.

14 Halme S, Syrjala H, Bloigu A., et al. Lymphocyte responses to chlamydia antigens in patients with coronary heart disease. Eur Heart f 1997; 18:1095-101.

15 Molestina RE, Dean D, Miller RD, et al. Characterization of a strain of Chlamydia pneumoniae isolated from a coronary activity in human endothelial cells. Infect Immun 1998;66: 1370-6.

$16 \mathrm{Kol}$ A, Sukhova GK, Lichtman AH, et al. Chlamydial heat shock protein 60 localizes in human atheroma and regulates macrophage tumor necrosis factor-alpha and matrix metalloproteinase expression. Circulation 1998;98: 300-7.

17 Tiran A, Tio RA, Ossewaarde JM, et al. Coronary angioplasty induces a rise in Chlamydia pneumoniaespecific antibodies. F Clin Microbiol 1999;37:1013-17.

18 Mayr M, Metzler B, Kiechl S, et al. Endothelial cytotoxicity mediated by serum antibodies to heat shock proteins of Escherchia coli and Chlamydia pneumoniae. Immune reactions to heat shock proteins as a possible link between infection and atherosclerosis. Circulation 1999;99:1560-6.

19 Muhlestein JB, Anderson JL, Hammond EH, et al. Infection with Chlamydia pneumoniae accelerates the development of atherosclerosis and treatment with azithromycin prevents it in a rabbit model. Circulation 1998;97:633-6.

20 Laitinen K, Laurila A, Pyhala L, et al. Chlamydia pneumoniae infection induces inflammatory changes in the aortas of rabbits. Infect Immun 1997;65:4832-5.

21 Moazed TC, Kuo C, Grayston JT, et al. Murine models of Chlamydia pneumoniae infection and atherosclerosis. $\mathcal{f}$ Infect Dis 1997;175:883-90.

$22 \mathrm{Hu} \mathrm{H}$, Pierce GN, Zhong G. The atherogenic effects of chlamydia are dependent on serum cholesterol and specific

23 Kuo C, Campbell LA. Is infection with Chlamydia pneumoniae a causative agent in atherosclerosis? $\mathrm{Mol} \mathrm{Med}$ pneumoniae a causative

24 Fagerberg B, Gnarpe J, Gnarpe H, et al. Chlamydia pneumoniae but not cytomegalovirus antibodies are associated with future risk of stroke and cardiovascular disease. A prospective study in middle-aged to elderly men with treated hypertension. Stroke 1999;30:299-305.

25 Melnick SL, Shahar E, Folsom AR, et al. Past infection by Chlamydia pneumoniae strain TWAR and asymptomatic carotid atherosclerosis. Atherosclerosis risk in communities (ARIC) study investigators. Am f Med 1993;95:499-504.

26 Ossewaarde JM, Feskens EJ, De Vries A, et al. Chlamydia pneumoniae is a risk factor for coronary heart disease in symptom-free elderly men, but Helicobacter pylori and cytomegalovirus are not. Epidemiol Infect 1998;120:93-9.

27 Laurila A, Bloigu A, Nayha S, et al. Chronic Chlamydia pneumoniae infection is associated with a serum lipid propneumoniae infection is associated with a serum lipid proThromb Vasc Biol 1997;17:2910-13.

28 Boman J, Soderberg S, Folsberg J, et al. High prevalence of Chlamydia pneumoniae DNA in peripheral blood monohuclear cells in patients with cardiovascular disease and in middle-aged blood donors. F Infect Dis 1998;178:274-7.

29 Wong YK, Dawkins K, Ward ME. Detection of C. pneumoniae DNA circulating in the blood of patients attending for cardiac angiography: preliminary clinical and serological correlates. In: Stephens RS, Byrne GI, Christiansen G, et al, eds. Chlamydial infections. Proceedings of the ninth al, eds. Chlamydral infections. Proceedings of the ninth International Chlamydial Symposium, San Francisco. 1998: 227-30.

30 Sinisalo J, Matilla K, Nieminen MS, et al. The effect of prolonged doxycycline therapy on Chlamydia pneumoniae serological markers, coronary heart disease risk factors and forearm basal nitric oxide production. If Antimicrob Chemother 1998;41:85-92.

31 Ridker PM, Kundsin RB, Stampfer MJ, et al. Prospective study of Chlamydia pneumoniae IgG seropositivity and risk of future myocardial infarction. Circulation 1999:99: 1161-4.

32 Altman R, Rouvier J, Scazziota A, et al. Lack of association between prior infection with Chlamydia pneumoniae and acute or chronic coronary artery disease. Clin Cardiol 1999; 22:85-90.

33 Yamashita K, Ouchi K, Shirai M, et al. Distribution of Chlamydia pneumoniae infection in the atherosclerotic chlamydia pneumoniae infection in artery. Stroke 1998;29:773-8.

34 Jackson LA, Campbell LA, Kuo CC, et al. Isolation of Chlamydia pneumoniae from a carotid endarterectomy specimen. F Infect Dis 1997;176:292-5.

35 Maass M, Krause E, Engel PM, et al. Endovascular presence of Chlamydia pneumoniae in patients with hemodynamically effective carotid artery stenosis. Angiology 1997:48: 699-706.

36 Grayston JT, Kuo CC, Coulson AS, et al. Chlamydia pneumoniae (TWAR) in atherosclerosis of the carotid artery. Circulation 1995;92:3397-400.

37 Davidson M, Kuo CC, Middaugh JP, et al. Confirmed previous infection with Chlamydia pneumoniae (TWAR) and its presence in early coronary atherosclerosis. Circulation
1998;98:628-33. 
38 Blasi F, Denti F, Erba M, et al. Detection of Chlamydia pneumoniae but not Helicobacter pylori in atherosclerotic plaques of aortic aneurysms. F Clin Microbiol1996;34: 2766-9.

39 Muhlestein JB, Hammond EH, Carlquist JF, et al. Increased incidence of chlamydia species within the coronary arteries of patients with symptomatic atherosclerotic versus other forms of cardiovascular disease. $\mathcal{F}$ Am Coll Cardiol 1996;27 1555-61.

40 Kuo CC, Coulson AS, Campbell LA, et al. Detection of Chlamydia pneumoniae in atherosclerotic plaques in the walls of arteries of lower extremities from patients undergoing bypass operation for arterial obstruction. $\mathcal{F}$ Vasc Surg 1997;26:29-31.

41 Kuo CC, Grayston JT, Campbell LA, et al. Chlamydia pneumoniae (TWAR) in coronary arteries of young adults (15-34 years old). Proc Natl Acad Sci U S A 1995;92:6911-14.

42 Kuo CC, Gown AM, Benditt EP, et al. Detection of Chlamydia pneumoniae in aortic lesions of atherosclerosis by immunocytochemical stain. Arterioscler Thromb 1993; 13:1501-4

43 Bartels C, Maass M, Bein G, et al. Detection of Chlamydia pneumoniae but not cytomegalovirus in occluded saphenous vein coronary artery bypass grafts. Circulation 1999;99: 879-82.

44 Maass M, Bartels C, Engel PM, et al. Endovascular presence of viable Chlamydia pneumoniae is a common phenomenon in

45 Juvonen JJ, Tuvonen T, Laurila A, et al. Demonstration of Chlamydia pneumoniae in the walls of abdominal aortic aneurysms. F Vasc Surg 1997;25:499-505.

46 Ramirez JA, Ahkee S, Summersgill JT, et al. Isolation of Chlamydia pneumoniae from the coronary artery of a patient with coronary atherosclerosis. Ann Intern Med 1996;125:979-82. 47 Shor A, Phillips JL, Ong G, et al. Chlamydia pneumoniae in
atheroma - consideration of criteria for causality. $\mathcal{f}$ Clin Pathol 1998;51:812-17.

48 Nystromrosander C, Thelin S, Hjelm E, et al. High incidence of Chlamydia pneumoniae in sclerotic heart valves of patients undergoing aortic valve replacement. Scand 7 Infect Dis 1997;29:361-5.

49 Paget CJ, Wolk SW, Whitehouse WM, et al. Incidence and pathophysiologic significance of infected carotid artery pathophysiologic significance of infected
plaque. Ann Vasc Surg 1997;11:129-32.

50 Paterson DL, Hall J, Rasmussen SJ, et al. Failure to detect Chlamydia pneumoniae in atherosclerotic plaques of AusChlamydia pneumoniae in atherosclerotic plact
tralian patients. Pathology 1998;30:169-72.

51 Lindholt JS, Osterdard L, Henneberg EW, et al. Failure to demonstrate Chlamydia pneumoniae in symptomatic abdominal aortic aneurysms by a nested polymerase chain reaction (PCR). Eur $\mathcal{F}$ Vasc Endovasc Surg 1998;15:161-4.

52 Andreasen JJ, Farholt S, Jensen JS. Failure to detect Chlamydia pneumoniae in calcific and degenerative arteriosclerotic aortic valves excised during open heart surgery. APMIS 1998;106:717-20.

53 Gupta S, Leatham EW, Carrington D, et al. Elevated Chlamydia pneumonia antibodies, cardiovascular events and azithromycin in male survivors of myocardial infarction. Circulation 1997;96:404-7.

54 Gurfinkel E, Bozovich G, Daroca A, et al. Randomized trial of roxithromycin in non-Q-wave coronary syndromes: ROXIS pilot study. Lancet 1997;350:404-7.

55 Gurfinkel E, Bozovich G, Beck E, et al. Treatment with the antibiotic roxithromycin in patients with acute non-Q-wave coronary syndromes. The final report of the ROXIS study. Eur Heart $\mathcal{F}$ 1999;20:121-7.

56 Anderson JL, Muhlestein JB, Carlquist J, et al. Randomized secondary prevention trial of azithromycin in patients with coronary artery disease and serological evidence for Chlamydia pneumonia infection. Circulation 1999;99: 1540-7.

57 Gibbs RG, Carey N, Davies AH. Chlamydia pneumoniae and vascular disease. Br F Surg 1998;85:1191-7.

58 Stille W, Dittmann R. Arteriosclerosis as a sequela of chronic Chlamydia pneumoniae infection. Herz 1998;23 185-92

59 Maass M. Persistence of Chlamydia pneumoniae in human arteriosclerotic plaque substance. Evidence and consequences. Herz 1998;23:187-4.

60 Das UN. Hypothesis: cis-unsaturated fatty acids as potential anti-peptic ulcer drugs. Prostaglandins Leukot Essent Fatty Acids 1998;58:377-80.

61 Laurila A, Bloigu A, Nayha S, et al. Association of helicobacter infection with elevated serum lipids. Atherohelicobacter infection with
sclerosis 1999;142:207-10.

62 Markus HS, Mendall MA. Helicobacter pylori infection: a risk factor for ischaemic cerebrovascular disease and carotid atheroma. I Neurol Neurosurg Psychiatry 1998;64: $104-7$

63 Birnie DH, Holme ER, McKay IC, et al. Association between antibodies to heat shock protein 65 and coronary atherosclerosis. Possible mechanism of action to Helicobacter pylori and other bacterial infections in increasing cardiovascular risk. Eur Heart $\mathcal{F}$ 1998;19:387-94.

64 Ossei-Gerning N, Moayyedi P, Smith S, et al. Helicobacter pylori infection is related to atheroma in patients undergo-

65 Folsom AR, Nieto FJ, Sorlie P, et al. Helicobacter pylori seropositivity and coronary heart disease incidence. Atherosclerosis risk in communities (ARIC) study investigators. Circulation 1998;98:845-50.
66 Regnstrom J, Jovinge S, Bavenholm P, et al. Helicobacter pylori seropositivity is not associated with inflammatory parameters, lipid concentrations and degree

67 Pesonen E, Paakkari I, Rapola J. Infection-associated intimal thickening in the coronary arteries of children. Atherosclerosis 1999; 142:425-9.

68 Constans J, Marchand JM, Conri C, et al. Asymptomatic atherosclerosis in HIV-patients: a case control ultrasound study. Ann Med 1995;27:683-5.

69 Paton P, Tabib A, Loire R, et al. Coronary lesions and immunodeficiency virus infection. Res Virol 1993;144:22531.

70 Iiback NG, Mohammed A, Fohlman J, et al. Cardiovascular lipid accumulation with Coxsacki B virus infection in mice. Am f Pathol 1990;136:159-67.

71 Roivainen M, Alfthan G, Jousilahti P, et al. Enterovirus infections as a possible risk factor for myocardial infarction. Circulation 1998;98:2534-7.

72 Nicholls AC, Thomas M. Coxsacki virus infection in acute myocardial infarction. Lancet 1977;1:883-4.

73 Griffiths PD, Hannington G, Booth JC. Coxsacki B virus infection and myocardial infarction. Lancet 1980;1;1387-9.

74 Vercellotti GM. Effects of viral activation of the vessel wall on inflammation and thrombosis. Blood Coagul Fibrinolysis 1998;9:S3-6.

75 Speir E, Yu ZX, Ferrans VJ, et al. Aspirin attenuates cytomegalovirus infectivity and gene expression mediated by cyclooxygenase-2 in coron
cells. Circ Res 1998;83:210-16.

76 Span AH, Van Boven CP, Bruggeman CA. The effect of cytomegalovirus infection on the adherence of polymorphonuclear leucocytes to endothelial cells. Eur f Clin Invest 1989;19:542-8.

77 Guetta E, Guetta V, Shibutani T, et al. Monocytes harboring cytomegalovirus: interactions with endothelial cells, smooth muscle cells, and oxidized low-density lipoprotein. Possible mechanisms for activating virus delivered by
monocytes to sites of vascular injury. Circ Res 1997;81:816 .

78 Yonemitsu Y, Kaneda Y, Komori K, et al. The immediate early gene of human cytomegalovirus stimulates vascular smooth muscle cell proliferation in vitro and in vivo. Biochem Biophys Res Commun 1997;231:447-51.

79 Melnick JL, Petrie BL, Dreesman GR, et al. Cytomegalovirus antigen within human arterial smooth muscle cells. Lancet $1983 ; 2: 644-7$

80 Berencsi K, Endresz V, Klurfeld D, et al. Early atherosclerotic plaques in the aorta following cytomegalovirus infection of mice. Cell Adhes Commun 1998;5:39-47.

81 Persoons MC, Daemen MJ, Bruning JH, et al. Active cytomegalovirus infection of arterial smooth muscle cells in immunocompromised rats A clue to herpesvirusassociated atherogenesis? Circ Res 1994; 75:214-20.

82 Sorlie PD, Adam E, Melnick SL, et al. Cytomegalovirus/ herpesvirus and carotid atherosclerosis: the ARIC study. $\mathcal{F}$ Med Virol 1994;42:33-7.

83 Nieto FJ, Adam E, Sorlie P, et al. Cohort study of cytomegalovirus infection as a risk factor for carotid intimal-medial thickening, a measure of subclinical atherosclerosis. Circulation 1996;94:922-7.

84 Herzum M, Schaefer JR, Hufnagel G, et al. Cytomegalovirus and herpes simplex virus in pathogenesis and progression of native arteriosclerosis and recurrent stenosis after intervention. Herz 1998;23:193-6.

85 Blum A, Giladi $M$, Weinberg $M$, et al. High anticytomegalovirus (CMV) IgG antibody titer is associated with coronary artery disease and may predict postcoronary balloon angioplasty restenosis. Am $\mathcal{f}$ Cardiol 1998;81:866-8.

86 Adam E, Melnick JL, Probtsfield JL, et al. High levels of cytomegalovirus antibody in patients requiring vascular surgery for atherosclerosis. Lancet 1987;2:291-3.

87 Visseren Fl, Bouter KP, Pon MJ, et al. Patients with diabetes mellitus and atherosclerosis; a role for cytomegalovirus? Diabetes Res Clin Pract 1997;36:49-55.

88 Musiani M, Zerbini ML, Muscari A, et al. Antibody patterns against cytomegalovirus and Epstein-Barr virus in human atherosclerosis. Microbiologica 1990;13:35-41.

89 Adler SP, Hur JK, Wang JB, et al. Prior infection with cytomegalovirus is not a major risk factor for angiographically demonstrated coronary artery atherosclerosis. F Infect Dis 1998;177:209-12.

90 Tiran A, Tio RA, Oostenveld E, et al. Humoral immune response to human cytomegalovirus in patients undergoing percutaneous transluminal coronary angioplasty. Clin Diagn Lab Immunol 1999;6:45-9.

91 Hendrix MG, Salimans MM, van Boven CP, et al. High prevalence of latently present cytomegalovirus in arterial walls of patients suffering from grade III atherosclerosis. Am f Pathol 1990;136:23-8.

92 Hendrix MG, Dormans PH, Kitslaar P, et al. The presence of cytomegalovirus nucleic acids in arterial walls of athero-
sclerotic and nonatherosclerotic patients. Am $\mathcal{F}$ Pathol 1989;134:1151-7.

93 Yonemitsu Y, Komori K, Sueishi K, et al. Possible role of cytomegalovirus infection in the pathogenesis of human vascular diseases. Nippon Rinsho 1998;56:102-8.

94 Melnick JL, Adam E, Debakey ME. Cytomegalovirus and atherosclerosis. Eur Heart 7 1993;14:30-8.

95 Grattan MT, Moreno-Cabral CE, Starnes VA, et al. Cytomegalovirus infection is associated with cardiac allograft rejection and atherosclerosis. $尹 A M A \quad 1989 ; 261$ : 3561-6. 
96 Loebe M, Schuler S, Spiegelsberger S, et al. Cytomegalovirus infection and coronary sclerosis after heart transplantation. Deutsche Med Wochenschr 1990;115:1266-9.

97 Fang JC, Kinlay S, Kundsin R, et al. Chlamydia pneumoniae infection is frequent but not associated with coronary atherosclerosis in cardiac transplant recipients. $A m \mathcal{F}$ Cardiol 1998;82:1479-83.

98 Adam E, Melnick JL, DeBakey ME. Cytomegalovirus infection and atherosclerosis. Cent Eur $\mathcal{f}$ Public Health 1997;5:99-106.

99 Musiani M, Zerbini ML, Muscari A, et al. Antibody patterns against cytomegalovirus and Epstein-Barr virus in human atherosclerosis. Microbiologica 1990;13:35-41.

100 Yamashiroya HM, Ghosh L, Yang R, et al. Herpesviridae in the coronary arteries and aorta of young trauma victims. Am 7 Pathol 1988;130:71-9.

101 Straka F, Malek I, Stanek V, et al. Coronary disease in patients after heart transplantation. Cor Vasa 1993;35: 267-75.

102 Key NS, Vercellotti GM, Winkelmann JC, et al. Infection of vascular endothelial cells with herpes simplex virus enhances tissue factor activity and reduces thrombomodulin expression. Proc Natl Acad Sci U S A 1990;87: 7095-9.

103 Kaner RJ, Medina J, Nicholson AC, et al. Developmentally regulated herpesvirus plaque formation in arterial smooth regulated herpesvirus plaque formation
muscle cells. Circ Res 1993;73:10-14.

104 Hajjar DP, Pomerantz KB, Falcone DJ, et al. Herpes simplex virus infection in human arterial cells. Implications in arteriosclerosis. F Clin Invest 1987;80:1317-21.

105 Visser MR, Vercellotti GM. Herpes simplex virus and atherosclerosis. Eur Heart F 1993;14:39-42.

106 Key NS, Bach RR, Vercellotti GM, et al. Herpes simplex virus type I does not require productive infection to induce tissue factor in human umbilical vein endothelial cells. Lab Invest 1993;68:645-51.
107 Span AH, van Dam-Mieras MC, Mullers W, et al. The effect of virus infection on the adherence of leukocytes or effect of virus infection on the adherence of leukocytes or
platelets to endothelial cells. Eur F Clin Invest 1991;21: platelets

108 Visser MR, Jacob HS, Goodman JL, et al. Granulocytemediated injury to herpes simplex virus-infected human endothelium. Lab Invest 1989;60:296-304

109 Mattila KJ, Valtonen VV, Nieminen MS, et al. Role of infection as a risk factor for atherosclerosis, myocardial infarction, and stroke. Clin Infect Dis 1998;26:719-34.

110 Raza-Ahmad A, Klassen GA, Murphy DA, et al. Evidence of type 2 herpes simplex infection in human coronary arteries at the time of coronary artery bypass surgery. Can f Cardiol 1995;11:1025-9.

111 Bayad J, Galteau MM, Siest G. Viral theory of atherosclerosis. Role of cytomegalovirus. Ann Biol Clin (Paris) 1993; 51:101-7.

112 Jacob HS, Visser M, Key NS, et al. Herpes virus infection of endothelium: new insights into atherosclerosis. Trans $\mathrm{Am}$ Clin Climatol Assoc 1992;103:95-104.

113 Csonka E, Bayer PI, Buki K, et al. Influence of the measles virus on the proliferation and protein synthesis of aortic endothelial and smooth muscle cells. Acta Microbiologica Harica 1990;37:193-200.

114 Ridker PM, Cushman M, Stampfer MJ, et al. Plasma concentration of C-reactive protein and risk of developing peripheral vascular disease. Circulation 1998;97:425-8.

115 Torzewski J, Torzewski M, Bowyer DE, et al. C-reactive protein frequently colocalizes with the terminal complement complex in the intima of early atherosclerotic lesions of human coronary arteries. Arterioscler Thromb Vasc Biol 1998;18:1386-92.

116 Bachmeier K, Neu N, de la Maza LM, et al. Chlamydia infection and heart disease linked through antigenic mimicry. Science 1999;283:1335-9.

117 Nicoletti A, Kaveri S, Caligiuri G, et al. Immunoglobulin treatment reduces atherosclerosis in apo E knockout mice. f Clin Invest 1998;102:910-18. 


\section{Book reviews}

Biopsy Interpretation of Bone and Bone Marrow; Histology and Immunohistology in Paraffin and Plastic. Cytogenetics in collaboration with Rothman, R. 2nd ed. Frisch B, Bartl R. (£95.00.) Arnold, 1999. ISBN 034074089 2.

This book is beautifully produced and, as one would expect from these two authors, is generally very well illustrated. It is based largely on the authors' very extensive experience of trephine biopsy histology and is therefore not extensively referenced. In contrast to the previous edition, illustrations are now derived from sections of paraffin wax embedded as well as plastic embedded biopsy specimens; pathologists from countries where plastic embedding is little used will appreciate this feature. Illustrative diagrams are clear and helpful and the literary style is clear.

Despite the title, this book deals only with the interpretation of histological features of core biopsies (or open biopsies). Aspiration biopsy of the bone marrow is largely ignored and I succeeded in finding only a single photograph of an aspirate - a Perls's stain of ring sideroblasts. This will be a definite disadvantage for many haematologists and may encourage histopathologists to undervalue the role of aspiration cytology.

A third of the book deals with bone histology. This section is particularly comprehensive and useful. It also serves to remind the reader of the close relation between bone and bone marrow, and of the influence of bone disease on bone marrow histology. Perhaps this section of the book will encourage both histopathologists and haematologists to make a careful assessment of the bone before turning their attention to the haemopoietic tissue.

The two thirds of the book that deals with the bone marrow gives a detailed account of bone marrow histology. Although bone marrow aspirates are not discussed some consideration is given to immunophenotyping and cytogenetic analysis. There are no serious omissions.

Are there any problems with this book? I found some of the illustrations to be at too low a power to be really informative. I also regretted the lack of information on magnification; there is not always a ready point of reference so that the reader may be able to get an impression of the size of any abnormal cells. In the latter fault this book is not unique; it is one of many contemporary histopathology textbooks that do not feel the need to inform the reader of the magnification of the photomicrographs.

If one wished to find individual errors a careful reading will unearth several. The authors carry over from the previous edition the concept that paratrabecular infiltration is not seen in centroblastic/centrocytic lymphoma whereas a nodular pattern of infiltration is common; this puzzling observation is contrary to the findings of most other haematopathologists. The grouping of very diverse inherited and acquired conditions under the heading of "Langerhans cell histiocytosis" is unhelpful, and at least one of the translocations given as characteristic of malignant histiocytosis in this table is much more typical of anaplastic large cell lymphoma, indicating previous diagnostic confusion between these two conditions. The authors' use of the term "granuloma" to describe the focal lesions of systemic mastocytosis is confusing, as is their use of the term "biopsy" to describe tissue obtained after death. Nevertheless, in a book of 367 pages, covering such a large field, mistakes are probably inevitable and one can only sympathise. The authors probably became aware of many of these errors shortly after publication.

Overall, a well illustrated account of bone marrow histology with bone histology being a particular strength.

B J BAIN

Histological Typing of Ovarian Tumours, 2nd ed. Scully RE. (£49.50.) World Health Organisation, Springer, 1999. ISBN 3540640592.

The World Health Organisation's histological typing of ovarian tumours (second edition) aims to establish definitions of tumour types to aid worldwide uniformity and reporting of ovarian tumours.

This short book includes an extensive morphological classification, including FIGO and TNM systems, preceded by definitions and explanatory notes.

There then follows a collection of 150 half page $(108 \times 70 \mathrm{~mm})$ predominantly full colour illustrations of each of the types outlined in the classification.

Most of the illustrations are excellent and help with newly described lesions, such as borderline serous tumours with a micropapillary pattern, and tricky types such as clear cell carcinoma with oxyphilic cytoplasm or containing bull's eye mucin accumulations. Occasionally, the illustrations are marred by section artefact or inconsistencies. Figure legend 98 asserts that yolk sac tumour can be distinguished from dysgerminoma by the presence of glandular spaces. Yet, fig 92 of a dysgerminoma shows similar spaces that resemble gland-like structures.

There is significant overlap with the AFIP fasicle on tumours of the ovary because the two publications share a common author. Unfortunately, every time an AFIP illustration is used the full reference is appended to the figure legend. This is unnecessarily repetitive.

It is convenient to be able to flick through the collection of illustrations but slightly tedious to refer to a preceding section for the text description. Nevertheless, this is an excellent graphical aid to correct tumour classification. It should be made available to anyone reporting ovarian surgical samples.

L J R BROWN

\section{Calendar of events}

Full details of events to be included should be sent to Maggie Butler, Technical Editor 7CP, The Cedars, 36 Queen Street, Castle Hedingham, Essex CO9 3HA, UK; email: maggiebutler@pilotree.prestel.co.uk

Recent Advances in Genetics

5 July 2001, Royal College of Pathologists, London, UK

Further details: Michelle Casey, Academic Activities Coordinator, 2 Carlton House Terrace, London SW1Y 5AF, UK. (Tel +44 020 7451 6700; fax +44 0207451 6701; www.rcpath.org)

\section{BSCC Annual Scientific Meeting}

9-11 September 2001, Majestic Hotel, Harrogate, UK

Further details: BSCC Office, PO Box 352, Uxbridge UB10 9TX, UK. (Tel +44 01895 274020; fax +44 01895 274080; email lesley.couch@psilink.co.uk)

Current Concepts in Surgical Pathology 12-16 November 2001, The Four Seasons Hotel, Boston, Massachusetts, USA

Further details: Department of Continuing Education, Harvard Medical School, PO Box 825, Boston, MA02117-0825. (Tel +1 617 432 1525; Fax +1 617432 1562; email hmscme@harvard.edu; web page http:// www.med.harvard.edu/conted/)

\section{1st St Andrew's Day Festival} Symposium on Therapeutics 6-7 December 2001, Royal College of Physicians, Edinburgh, UK

Further details: Eileen Strawn, Symposium Coordinator. (Tel +44 0131225 7324; fax +44 $0131 \quad 220 \quad 4393$; email 2.strawn@rcpe.ac.uk; website www.rcpe.ac.uk)

\section{Correction}

Microorganisms in the aetiology of atherosclerosis. Morré SA, Stooker W, Lagrand WK, et al. F Clin Pathol 2000;53:647-54.

In the acknowledgements section of this paper, with regard to the financial funding of Dr Niessen by the Dr E Dekker programme of the Dutch Heart Foundation, the grant number (D99025) was omitted. The authors apologise for this oversight. 


\section{Q1 Best Practice articles (formerly "Broadsheets") prepared by the Association of Clinical Pathologists}

\section{Just published}

164 Necropsy techniques in ophthalmic pathology 2001 MA PARSONS, RD START

163 Wilson's disease: acute and presymptomatic laboratory diagnosis and monitoring 2000 D GAFFNEY, GS FELL, D ST J O'REILLY

162 The histological reporting of melanoma 2000 E CALONJE

161 Examination of lung specimens 2000 AR GIBBS, RL ATTANOOS

160 Renal biopsy specimens 2000 PN FURNESS

159 Examination of large intestine resection specimens 2000 SH BURROUGHS, GT WILLIAMS

158 Neuropathology 2000 WR TIMPERLEY

157 Guidelines for the laboratory handling of laryngectomy specimens 2000 TR HELLIWELL

156 Handling oesophageal biopsies and resection specimens and their reporting 2000 NBN IBRAHIM

\section{Recent Publications}

155 Pathological investigation of deaths following surgery, anaesthesia, and medical procedures 1999 RD START, SS CROSS

154 Helicobacter pylori 1999 CAM MCNULTY, JI WYATT (with correction in June issue)

\section{Other Best Practice articles are still available for purchase}

153 The laboratory investigation of vaginal discharge 1998 KF MACSWEEN, GL RIDGWAY

152 Clinical implications of plasma homocysteine measurement in cardiovascular disease 1998 RA STILL, IFW MCDOWELL

151 Investigation of dyslipidaemias 1997 AF WINDER, W RICHMOND, DT VALLANCE

150 Antenatal serological testing and prevention of haemolytic disease of the newborn 1997 JKM DUGUID

149 Serological diagnosis of gluten sensitive enteropathy 1996 DJ UNSWORTH

148 Laboratory diagnosis of malaria 1996 DC WARHURST, JE WILLIAMS

147 Mycological techniques 1996 KG DAVEY, CK CAMPBELL, DW WARNOCK

146 Macroscopic examination of prostatic specimens 1995 P HARNDEN, MC PARKINSON
Earlier Broadsheets may still be available from the author. A full list can be obtained from the Publications Secretary, Association of Clinical Pathologists, 189 Dyke Road, Hove, East Sussex BN3 $1 T L$.

\section{Prices}

INLAND One copy, $£ 2.50 ; 2-10$ copies (of any one broadsheet or reprint), $£ 2.00$ each; $11-100$ copies (of any one), $£ 1.75$ each; 101 plus copies (of any one), price to be agreed; authors (over 50 free copies), 1.25 each.

OVERSEAS One copy, $\$ 6.75 ; 2-10$ copies (of any one broadsheet or reprint), $\$ 5.25 ; 11-100$ copies (of any one), $\$ 3.75$; 101 plus copies (of any one), price to be agreed.

Authors $\$ 2.25$. Prices include postage but air mail will be charged extra. Trade discount $10 \%$. All orders (and all changes of address of regular subscribers) should be sent to the Publishing Manager • Fournal of Clinical Pathology, BMJ Publishing Group, BMA House, Tavistock Square, London WC1H 9JR. 